Case Report

\title{
RHIZOBIUM RADIOBACTER BACTEREMIA IN A TWO- YEAR-OLD PATIENT WITH AN ACUTE LYMPHOBLASTIC LEUKEMIA: A CASE REPORT
}

Biljana Kakaraskoska Boceska ${ }^{1}$, Dugagjin Osmani ${ }^{1}$, Branka Petrovska Basovska ${ }^{1}$, Verica Kakaraskoska Petreska², Kata Martinova ${ }^{3}$, Zorica Antevska Trajkova³, Aleksandra Jovanovska3, Svetlana Kocheva ${ }^{3}$

1 Institute of Public Health of Republic of North Macedonia, Skopje

${ }^{2}$ Health Centre, Prilep, Republic of North Macedonia

3 University Clinic for Pediatric Diseases, Skopje, Republic of North Macedonia

Citation: Kakaraskoska Boceska B, Osmani D, Petrovska Basovska B, Kakaraskoska Petreska V, Martinova K, Antevska Trajkova Z, Jovanovska A, Kocheva S. Rhizobium radiobacter bacteremia in a two-year-old patient with an acute lymphoblastic leukemin: a case report Arch Pub Health blastic leuke 2020; 12 (3).

doi.org/10.3889/aph.2020.5612

Key words: Rhizobium radiobacter, malignancy, central venous catheter, immunocompromised, cephalosporins

*Correspondence: Biljana Kakaraskoska Boceska. Institute for Public Health of Republic of North Macedonia, Skopje, Republic of North Macedonia E-mail: kakaraskoska@yahoo.com

Received: 25-Oct-2020; ; Revised: 27-Nov-2020 Accepted: 12-Dec-2020; Published: 15-Dec-2020

Copyright: ${ }^{\circledR}$ 2020. Biljana Kakaraskoska Boceska This is an open-access article distributed unde the terms of the Creative Commons Attribution License, which permits unrestricted use, distribution, and reproduction in any medium, provided the original author(s) and source are credited.

Competing Interests: The author have declared that no competing interests

\section{Abstract}

Rhizobium radiobacter is a Gram-negative rod-shaped bacterium usually associated with diseases in plants. Infections due to $R$. radiobacter in humans are strongly related to the presence of foreign plastic materials, immunocompromised and chronically debilitated hosts with underlying conditions such as malignancies, human immunodeficiency virus as well as bone marrow transplant recipients. The aim of this paper was to present a rare blood infection with Rhizobium radiobacter in North Macedonia in a pediatric patient with underlying conditions. The treatment was successful with appropriate cephalosporin and aminoglycoside therapy without removing the central venous catheter

\section{Студија на случај}

\section{БАКТЕРИЕМИЈА ПРЕДИЗВИКАНА ОД RHIZOBIUM RADIOBACTЕR КАЈ ДВЕГОДИШЕН ПАЦИЕНТ СО АКУТНА ЛИМФОБЛАСТНА ЛЕУКЕМИЈА: ПРИКАЗ НА СЛУЧАЈ}

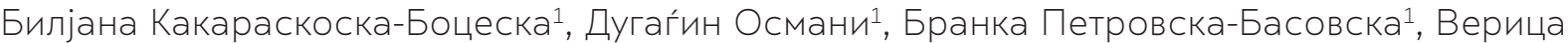
Какараскоска-Петреска², Ката Мартинова ${ }^{3}$ Зорица Антевска-Трајковаㄹ, Александра Јовановска ${ }^{3}$ Светлана Кочева ${ }^{3}$

\author{
Инсйитиуй за јавно зяравје на Рейублика Северна Макеgонија, Скойје \\ Зяравсиивен gом, Прилей, Реӣублика Северна Макеgонија \\ Клиника за gейски болесйи, Скойје, Рейублика Северна Макеgонија
}

Цитирање: Какараскоска-Боцеска Б, Османи Д, Петровска-Басовска Б, Какараскоска-Пе треска В, Мартинова K, Антевска-Трајкова 3 , Јовановска А, Кочева С. Бактериемија предиз викана од Rhizobium radiobacter кај двегодишен пациент со акутна лимфобластна леукемија: приказ на случај. Арх J Здравје 2020;12(3 doi.org/10.3889/aph.2020.5612

Клучни зборови: Rhizobium radiobacter, малигнитет, централен венски катетер, имунокомпромитиран, цефалоспорини

*Кореспонденција: Билјана Какараскоска-Боцеска, Институт за јавно здравје на Република Северна Македонија, Скопје, E-mail: kakaraskoska@yahoo.com

Примено:25-окт-2020;Ревидирано:27-ное-2020; Прифатено: 12-дек-2020; Објавено: 15-дек-2020 Печатарски права: ${ }^{\circledR 2020 ~ Б и л ј а н а ~ К а к а р а с к о-~}$ ска-Боцеска. Оваа статија е со отворен пристап дистрибуирана под условите на нелокализирана лиценца, која овозможува неограничена употре ба, дистрибуција и репродукција на било ко медиум, доколку се цитираат оригиналниот(ите) автор(и) и изворот.

Конкурентски интереси: Авторот изјавува дека нема конкурентски интереси.

\section{Извадок}

Rhizobium radiobacter е Грам-негативна стапчеста бактерија најчесто поврзана со болести кај растенијата. Кај луѓето, инфекциите предизвикани од R. radiobacter ce строго поврзани со присуство на материјали од пластика, имунокомпромитирачки и хронични состојби кај пациенти со основни заболувања како малигнитети, СИДА (или присуство на вирус на хумана имунодефициенција), како и кај пациенти со трансплантирана коскена срцевина. Целта на овој труд беше да се прикаже редок случај на инфекција на крвта предизвикана од Rhizobium radiobacter кај педијатриски пациент со акутна лимфобластна леукемија како основно заболување. Терапијата беше успешно спроведена со соодветна цефалоспоринска и аминогликозидна терапија, без отстранување на централниот венски катетер. 


\section{Introduction}

Bacteria from genus Rhizobium (formerly Agrobacterium) are plant pathogens and usually associated with tumorigenic disease in plants ${ }^{1,2}$. In 2001, Agrobacterium species and Allorhizobium undicola have been reclassified in the genus Rhizobium, based on comparative 16S rRNA gene analyses and proposed to contain five species ( $R$. radiobacter, $R$. rhizogenes, $R$. rubi, R. undicola and R. vitis) ${ }^{3}$. R. radiobacter is the only species of the genus known to cause human diseases and recognized as an opportunistic pathogen ${ }^{4,5}$. Infections due to R. radiobacter are strongly related to the presence of foreign plastic materials, and effective treatment often requires removal of the device ${ }^{5,6,7}$. Catheter-related bacteremia, continuous ambulatory peritoneal dialysis peritonitis, urinary tract infections and rarely endophthalmitis, endocarditis, brain abscess and pneumonia are the most common clinical conditions caused by these bacteria ${ }^{8,9}$. Identification of clinical isolates by molecular methods, such as rRNA gene analysis, has been described only in few studies $^{10,11}$.

The aim of the study was to present a rare blood infection with Rhizobium radiobacter in a pediatric patient with acute lymphoblastic leukemia.

Case report: On 27.12.2019, a 2-yearold boy was hospitalized at the University Clinic for Pediatric Diseases in Skopje, R. North Macedonia, with diagnosis acute lymphoblastic leukemia (pre B-ALL).

On 31.12.2019 therapy (ALL-IC 2002; BFM protocol) was started. On the 33rd day of the treatment, morphological and molecular remission of the primary illness was accomplished. The therapy was conducted through central venous catheter (CVK), allocated on 23.01.2020. Protocol therapy was completed on 30.03.2020.

During the recovery period, after long term myelosuppression, on 24.03.2020 the child became febrile - $38.6^{\circ} \mathrm{C}$. Blood sample was collected from CVK, with complete aseptic precaution, into pediatric blood culture bottle for aerobic and anaerobic bacteria (PediBact/BactAlert, Biomerieux, France). Blood sample beeped positive after few hours of incubation. Aliquot of broth was sub-cultured on $10 \%$ sheep blood agar and Mueller Hinton-F agar [culture medium with $5 \%$ horse blood plus $\beta$-NAD ( $\beta$-Nicotinamide Adenine Dinucleotide (MHF)]. After 18h of incubation, non-hemolytic, grey colonies, 1-2 mm size, circular, smooth, glistening, with entire edges were grown on blood agar, as well as on MHF agar (Picture 1). Using Gram negative identification card (Biomerieux, France), the isolate was identified as Rhizobium radiobacter with $99 \%$ probability on VITEK2 (fully automated identification system).

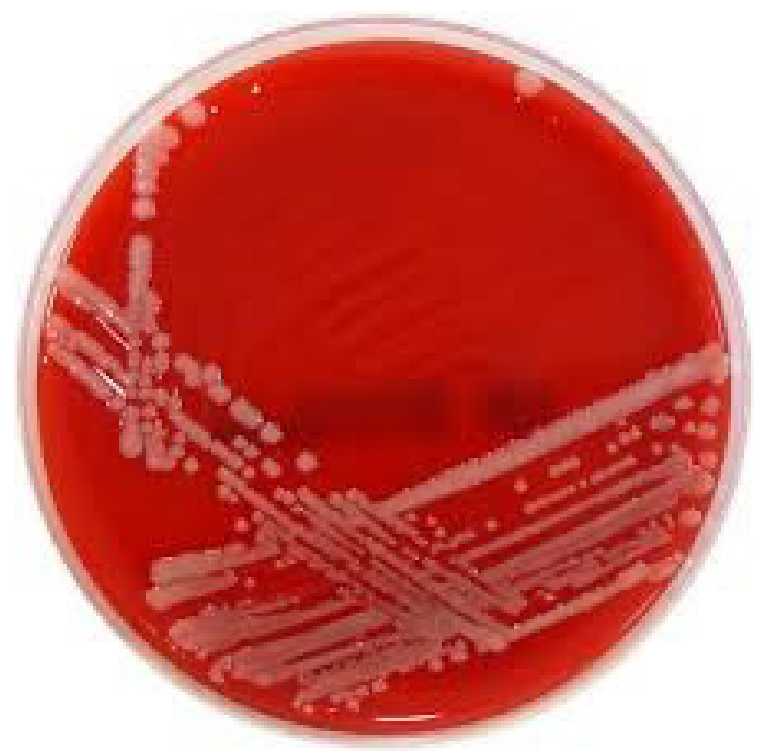

Picture 1. Non-hemolytic, grey colonies of Rhizobium radiobacter on Columbia blood agar

The isolate was found to be sensi- 
tive to ampicillin, amoxicillin with clavulanic acid, ceftriaxone, carbapenems, gentamicin, quinolones, amikacin, cephalosporins, except ceftazidime, which was resistant. I.v. cefotaxime was instituted as the fever started in 7 days and according to the culture results, solution of aminoglycoside was injected directly in the CVK. The same causative microorganism was confirmed in the second specimen, too. Other laboratory investigations made on 24.03.2020 revealed the following: total leukocyte count $-1.56 \times 10^{*} 9 / 1$, neutrophil $0.07 \times 10 * 9 / 1$, hemoglobin $79 \mathrm{~g} / \mathrm{l}$, erythrocyte $2.82 \times 10 * 12 / 1$, thrombocyte - 25×19*9/1. C-reactive protein (CRP) was $3.4 \mathrm{mg} / \mathrm{l}$.

Control blood sample was taken on 07.04.2020, one week after antibiotic application into CVK, and Rhizobium radiobacter was not detected.

Discussion: Before 1977, the growth of Rhizobium species has been mostly considered as laboratory contaminant or colonization rather than true infection11. Now it is recognized as an emerging opportunistic pathogen affecting mostly immunocompromised and chronically debilitated host with underlying conditions such as malignancies, chronic renal failure, human immunodeficiency virus as well as bone marrow transplant recipients. Corticosteroid therapy and diabetes have also been identified as predisposing factors6,8,11,12. In our case, severe neutropenia with ANC $70 / \mu l$ was probably the cause of the infection.

We made a thorough review of the medical literature and found few cases of $R$. radiobacter infection reported in children, but not a single one from North Macedonia8,13,14,15,16. Also, there are no reported cases infected with these pathogens in other age groups from N. Macedonia. In our case, bacteremia was associated with two underlying conditions: firstly, malignant disease, secondly, implicated central venous catheter and finally as the result of the immunosuppressive therapy, severe neutropenia appeared, as another risk factor for generating this bacteremia.

In most of the cases removal of foreign devices was required to treat bacteremia, but in many cases, as in ours, only antibiotic therapy without the removal of devices has also been successful1,6,11. Although there is no uniform opinion about the catheter removal, its use is recommended in cases of clinical deterioration, or when the culture remains positive 48 hours after initiated treatment15.

There are no clinical trials on the optimal therapy for Rhizobium radiobacter infection due to its low virulence and incidence. In our investigation, antimicrobial susceptibility pattern for Rhizobium radiobacter was sensitive to third generation cephalosporins, aminoglycosides, fluoroquinolones and carbapenems, consistent with the previous reports we found in the literature1,10,17,18,19. Our patient did not demonstrate any long-term consequences of this infection.

Conclusion: Rhizobium radiobacter is an opportunistic pathogen mainly affecting immunocompromised children. It has shown a high susceptibility pattern to many antibiotics which makes treatment much easier and successful. Usually, appropriate antibiotic therapy with foreign device removal is necessary to control infection, but in our case, only therapy with third generation cephalosporin and aminoglycoside directly applied into CVK was enough. 


\section{References}

1. Oncel EK, Ozsurekci Y, Aytac S, Kara A, Cengiz AB, Ceyhan M. Implantable vascular access port associated bloodstream infection caused by Rhizobium radiobacter: a case report. Turkish J Pediatr. 2013;55:112-15.

2. Mitrev S, Arsov E, Kovacevik B. Review of the most important bacterial disease in Republic of Macedonia. Yearbook, Institute of Southern Crops Strumica. 2005; 139-146.

3. Young JM, Kuykendall LD, MartinezRomero E, Kerr A, Sewada H. A revision of Rhizobium Frank 1889, with an emended description of the genus, and the inclusion of all species of Agrobacterium Conn 1942 and Allorhizobium undicola de Lajudie at al. 1998 as new combinations: Rhizobium radiobacter, $R$. rhizogenes, $R$. rubi, $R$. undicola and R. vitis. Int J Syst Evol Microbiol. 2001;51:89-103.

4. Lai CC, Teng LJ, Hsueh PR, et al. Clinical and microbial characteristics of Rhizobium radiobacter infections. Clin infect Dis 2004;38:149-43.

5. Mastroianni A, Coronado O, Nanetti A, Manfredi R, Chiodo F. Agrobacterium radiobacter pneumonia in a patient with HIV infection. Eur J Clin Microbial Infect Dis 1996; 15:960-963.

6. Alnor D, Frimodt-Moller N, Espersen F, Frederiksen W. Infections with unusual human pathogens Agrobacterium species and Ochrobacterium anthropi. Clin Infect Dis 1994;18:914920.

7. Mantadakis E, Kondi A, Christidou A, Kalmanti M. Agrobacterium radiobacter bacteremia in a child with acute lymphoblastic leukemia. World J Pediatr 2010;6:181-84.

8. Hammerberg O, Bialkowska-Hobrzanska H, Gopaul D. Isolation of Agrobacterium radiobacter from a central venous catheter. Eur J Clin Microbiol Infect Dis 1991;10:450-452.

9. Paphitou NI, Rolston KV. Catheterrelated bacteremia caused by Agrobacterium radiobacter in a cancer patient: case report and literature review. Infection 2003;31:421-24.

10. Christakis GB, Alexaki P, Alivizatos AS, et al. Primery bacteremia caused by Rhizobium radiobacter in a patient with solid tumors. J Med Microbiol 2006;55(10):1453-56.

11. Giammanco GM, Pignato S, Santangelo C, Grimont F, Giammanco G. Molecular typing of Agrobacterium species isolated from catheter-related bloodstream infections. Infect Control Hosp Epidemiol 2004; 25:885887.

12. Sood S, Nerukar V, Malvankar S. Catheter associated bloodstream infection caused by Rhizobium radiobacter. Indian J Med Microbiol 2010;28(I):62-64.

13. Rolides E, Mueller $\mathrm{Bu}$, Letterio JJ, Butler K, Pizzo PA. Agrobacterium radiobacter bacteremia in a child with human immunodeficiency virus infection. Pediatr Infect Dis 1991;10:33738.

14. Kaselitz TB, Hariadi NI, Lipuma JJ, Weinberg JB. Rhizobium radiobacter bacteremia in a neonate. Infection 2012;40:437-39.

15. Amaya RA, Edmonds MS. Agrobacterium radiobacter bacteremia in pediatric patients. Case report and review. Pediatr Infect Dis J 2003;22:183-86

16. Dunne WM, Jr, Tillman J, Murray JC. Recovery of a strain of Agrobacterium radiobacter with a mucoid phenotype from an immunocompromised child with bacteremia. J Cin Microbiol. 1993;31:2541-43.

17. Plotkin GR. Agrobacterium radiobacter prosthetic valve endodocarditis. Ann Intern Med 1980;93:839-40.

18. Ponnapula S, Swamson JM, Wood CG, Boucher BA, Wells DL, Croce MA, Fabian TC. Treatment of Rhizobium radiobacter bacteremia in a critically ill trauma patient. Ann Pharmacother 2013;47(11):1584-7.

19. Zhang HP, Fan JM, Huang DH, Zeng YM. Clinical and microbiological characteristics of Rhizobium radiobacter infections: six cases report and literature review. Zhonghua Jie He He Hu Xi Za Zhi 2010;33(2):93-8. 